\title{
DINAMIKA SOSIAL PEDAGANG DI PASAR BLAURAN KOTA PALANGKA RAYA
}

\author{
Sriyana \\ Fakultas IImu Sosial dan IImu Politik Universitas PGRI Palangka Raya \\ (email: riyanupp72@gmail.com) \\ Bumbun \\ Fakultas IImu Sosial dan IImu Politik Universitas PGRI Palangka Raya
}

\begin{abstract}
Abstrak
The descriptive study of Blauran Traditional Market Traders in Palangka Raya City was motivated by problems arising from the rapid emergence of modern markets which were feared to shift the existence of traditional markets in Palangka Raya City. Where the problems that occur in traditional markets greatly affect the existence of the traditional markets themselves, from the problems of services provided by traders to the most frequent problems that arise, namely regarding the cleanliness in traditional markets. This study aims to describe and analyze the social dynamics of traders in the Blauran traditional market, Palangka Raya City. While the research method is a qualitative method with a descriptive approach, with data collection techniques through interviews, observation and documentation study. The results showed that the Blauran traditional market traders instilled values and norms that had existed from generation to generation from generation to generation before them. So that traders can easily overcome problems that arise as a result of the emergence of modern markets, and with the development of the era traders provide other innovations from pre-existing values and practice them directly to buyers in order to provide comfort obtained from the work ethic produced directly by traders.
\end{abstract}

\section{Kata kunci : Dynamics, social, merchant, traditional}

\section{Pendahuluan}

Pasar tradisional merupakan salah satu institusi ekonomi yang penting dalam kehidupan masyarakat. Hal ini terlihat dari tetap eksisnya pasar tradisional baik di perkotaan maupun di pedesaan. Eksisnya pasar tradisional di tengah-tengah masyarakat tidak lain karena institusi pasar tradisional tersebut melekat pada masyarakat tersebut secara luas. Ini dapat terjadi apabila penyesuaian norma terbentuk, maka akan diikuti oleh penyesuaian struktur dan sumber daya. Keadaan ini menunjukkan bahwa institusi pasar tradisional tidak terlepas dari pengaruh hubungan masyarakat secara umum.

Disamping itu pasar juga menjadi tempat untuk memenuhi kebutuhan pokok masyarakat. Sebagai pusat ekonomi perkem-bangan pasar tradisional

\section{Jurnal Sociopolitico}


menjadi petunjuk awal perkembangan ekonomi masyarakat setempat dari susunan arus barang dan jasa, ciri khas pasar tradisional paling menonjol adalah berkaitan dengan jenis barang yang diperjualbelikan. Kendati tidak menutup kemungkinan dimasuk-kannya jenis-jenis barang yang bersifat tahan lama seperti; perabot rumah tangga dan bahan material untuk bangunan rumah, yang besar kecil tergantung pada pasar yang dimaksud. Sebagai pusat arus barang, pasar tradisional juga menjadi sentra perekonomian komoditas pertanian. Setiap daerah mempunyai komoditas tertentu, tetapi sering mengkonsumsi komoditas lain yang mereka butuhkan, karena setiap daerah belum tentu bisa memenuhi kebutuhannya sendiri akibat kondisi sosial, ekonomi dan geografis sehingga harus mendatangkan barang kebutuhan seharihari dari luar kota yang berdampak pada harga barang kebutuhan pokok.

Pasar tradisional adalah pasar yang dalam pelaksanaannya bersifat tradisional dan ditandai dengan pembeli serta penjual yang bertemu secara langsung. Proses jual-beli biasanya melalui proses tawar menawar harga, dan harga yang diberikan untuk suatu barang bukan merupakan harga tetap, dalam arti lain masih dapat ditawar, hal ini sangat berbeda dengan pasar modern (M. Fuad, 2000).

Pasar tradisional memiliki potensi, keunikan tersendiri serta budaya pasar menjadi daya tarik dan banyak diminati oleh para ekspatriat (pengunjung) maupun pelancong dari negara-negara modern dan menegaskan bahwa pasar tradisional sebetulnya menjadi ciri khas sebuah daerah).

Sejalan dengan hal tersebut, contoh dari keunggulan pasar tradisional terutama pada aspek budaya berbelanja yang sudah melekat pada masyarakat seperti bisa melakukan tawar menawar dalam bertransaksi dan pelayanan langsung. Keunggulan tersebut harus dikembangkan di tengah daya tarik pasar tradisional yang kian berkurang dibandingkan dengan pasar modern.

Pasar tradisional sampai sekarang dapat eksis karena memiliki kehidupan sosial layaknya masyarakat pedesaan, dimana hal ini tampak dengan adanya proses tawar menawar antara pedagang dan pembeli. Kecenderungan tersebut mengarah kepada hubungan antar individu didalamnya yang kebanyakan saling kenal yang mengarah pada hubungan langganan dagang. Ini menjadi dasar aktivitas-aktivitas sosial yang berhubungan satu sama lain antar aktor didalamnya yang sesuai dengan normanorma dan tradisi masyarakat setempat dalam kehidupan sosial ekonomi masyarakat setempat.

Pasar tradisional merupakan sektor perekonomian yang sangat penting bagi mayoritas penduduk di Indonesia. Masyarakat miskin yang bergantung kehidupannya pada pasar tradisional tidak sedikit, menjadi pedagang di pasar tradisional merupakan alternatif pekerjaan di tengah banyaknya pengangguran di Indonesia (Masitoh, 2013).

Dinamika pasar terjadi melalui interaksi dan aktivitas yang dilakukan oleh aktor-aktor pasar baik di tempat pasar (marketplace) maupun di luar tempat pasar. Tempat pasar merupakan suatu arena sosial yang digunakan oleh individuindividu untuk mengadakan hubunganhubungan sosial. Itu dapat diartikan bahwa pasar merupakan tempat dimana orang sibuk dalam hubungan-hubungan ekonomi dalam suatu mekanisme sosial.

\section{Jurnal Sociopolitico}


Dinamika sosial berarti bahwa manusia dan masyarakat selalu berkembang serta mengalami perubahan. Perubahan akan selalu ada dalam setiap kelompok sosial. Ada yang mengalami perubahan secara lambat, maupun mengalami perubahan secara cepat (Soekanto, 2006)

Untuk dapat memahami interaksi dan aktivitas pasar tradisional, perlu diketahui siapa-siapa saja atau kelompok-kelompok mana saja yang turut terlibat dalam aktivitas pasar tradisional. Orang-orang yang terlibat dalam aktivitas kegiatan pasar disebut sebagai aktor-aktor pasar. Secara umum dalam pasar tradisional terdapat beberapa aktor pasar yaitu distributor, pedagang perantara, pedagang, organisasi kepemudaan (pengelola pasar dan pengumpul pajak) dan konsumen.

Dalam kehidupan dinamika pasar tradisional selalu memiliki aktor ketiga, seperti halnya organisasi pemuda yang terlibat dalam sirkulasi barang dan jasa dalam pasar tradisional. Untuk mendapatkan sejumlah uang maka para pemuda tersebut melakukan hubungan kerja secara terikat terhadap para pedagang seperti; uang bongkar barang, uang parkir, uang sampah (kebersihan), uang lampu dan uang jaga malam (keamanan).

Salah satu pasar tradisional yang masih beroperasi di Kota Palangka Raya adalah Pasar Blauran. Pasar tradisional siang dan malam hari ini, dimana pelaku pasar adalah distributor, pedagang besar, pedagang kecil, dan organisasi pemuda yang melakukan aktivitasnya malam hari tepatnya pukul 19.00 WIB malam sampai pukul 07.00 WIB pagi sesuai dengan perannya masing-masing. Distributor sebagai penyalur barang yang ada di pasar
Blauran, pedagang besar sebagai penampung barang dari distributor yang kemudian dibeli pedagang kecil untuk dijual kembali ke pasar pagi yang tersebar di Kota Palangka Raya. Organisasi kepemudaan berperan sebagai pekerja yang memberi jaminan dalam bentuk jasa seperti membongkar barang, menyimpan barang, tukang parkir yang dimiliki pedagang sampai masalah kebersihan dan membersihkan sampah untuk memberi kenyamanan para pedagang dalam menjual hasil dagangannya.

Dari pernyataan di atas menunjukkan bahwa pasar merupakan sebuah sistem yang sangat kompleks, yang bukan saja menunjuk pada proses ekonomi tetapi juga sosialisasi di antara pelaku ekonomi guna memenuhi kebutuhan sehari-hari. Selain itu juga terjadinya dinamika sosial dan interaksi sosial dari pelaku yang ada di pasar Blauran, khususnya di kalangan pedagang pasar Blauran. Hal inilah yang menjadikan peneliti tertarik meneliti dinamika sosial pedagang yang ada di pasar Blauran Kota Palangka Raya.

Dinamika sosial bisa disebut sebagai sebuah perubahan dalam sebuah masyarakat akibat fenomena yang terjadi atau dialami dalam masyarakat tersebut. Dengan kata lain, antar anggota kelompok mempunyai hubungan psikologis yang berlangsung dalam situasi yang dialami secara bersama-sama. (Santosa, 2009).

\section{Metode Penelitian}

Jenis penelitian ini adalah penelitian kualitatif dengan menggunakan pendekatan deskriptif guna mendeskripsikan fenomena sosial seputar dinamika sosial antar pedagang dan distributor di pasar tradisional Blauran Kota Palangka Raya. subyek penelitian

\section{Jurnal Sociopolitico}


adalah pedagang tradisional yang hanya menjual barang dagangan pokok (pedagang sembako), pembeli dan pedagang di Pasar Tradisional Blauran Kota Palangka Raya. Penentuan jumlah subyek penelitian dilakukan secara purposif (purposive sampling). Teknik pengumpulan data menggunakan metode observasi wawancara, dan studi dokumentasi. Sedangkan teknik analisis data menggunakan analisis kualitatif.

\section{Hasil dan Pembahasan}

\section{Etos Kerja Pedagang}

Pedagang pasar Blauran Kota Palangka Raya memberikan pelayanan yang diperlukan demi menarik perhatian pembeli meskipun pedagang tidak memiliki karakter seperti yang ditunjukannya dalam aktivitas berdagang. Karena nilai-nilai itu diyakini dapat memberikan dampak positif bagi kemajuan usaha mereka sehingga mereka mengikuti apa yang telah mereka yakini dan mempraktekannya langsung meskipun karakter pedagang sangat berbeda dengan nilai-nilai tersebut. Kebiasan-kebiasaan seperti ramah, sopan, santun dan memberikan pelayanan dengan tersenyum merupakan cara menarik pembeli.

Etos kerja merupakan seperangkat perilaku positif yang berakar pada keyakinan fundamental yang disertai komitmen total pada paradigma kerja yang integral (Sinamo, 2011). Etos kerja merupakan nilai-nilai tertinggi dalam gagasan budaya masyarakat terhadap kerja yang dapat menjadi penggerak batin masyarakatnya melakukan kerja (Nurhana dalam Sarajar, 1995).

Berdasarkan hasil penelitian terlihat bahwa pedagang pasar Blauran Kota
Palangka Raya memperlihatkan etos kerja dengan cara berpenampilan yang menarik, sopan, rapi dan bersih. Hal ini dimaksudkan agar pembeli bisa tertarik untuk mampir ke kios/lapak tempat mereka jualan, dengan harapan mau membeli barang dagangan yang mereka jajakan.

Selain itu, etos kerja pedagang juga terlihat dari kesabaran pedagang pasar Blauran untuk memberikan pelayanan kepada calon pembeli dengan cara menjawab setiap pertanyaan yang ditanyakan oleh calon pembeli meskipun terkadang tidak jadi membeli.

Pada dasarnya etos kerja merupakan sikap dasar yang dimiliki seseorang maupun kelompok mengenai cara bekerja dan keinginan untuk menjunjung tinggi mutu pekerjaan, dan bahkan mampu meningkatkan prestasi kerja secara optimal dalam pemenuhan kebutuhan ekonominya. Seseorang memiliki berbagai sikap dalam menjalankan usahanya dapat dibentuk oleh berbagai kebiasaan dan budaya turun-temurun yang dimilikinya.

Tasmara (1995: 29-61) yang menyatakan bahwa seorang wirausaha dikatakan memiliki etos kerja yang positif jika dirinya memiliki sikap-sikap yang menjadi indikator etos kerja yang meliputi penuh perhitungan, menghargai waktu, hemat, kemampuan bersaing, mandiri, dan pantang menyerah.

Hal ini juga didukung oleh pendapat Mubyarto (1991) yang menyatakan bahwa etos kerja yang tinggi dimanifestasikan dalam kemauan seseorang untuk bekerja keras dan bersungguh-sungguh. Sikapsikap tersebut pedagang gunakan sebagai landasan dalam menjalankan usahanya dengan harapan bahwa usaha yang mereka jalankan pada akhirnya dapat memberikan hasil yang maksimal sehingga mereka

\section{Jurnal Sociopolitico}


dapat bertahan hidup dan memiliki penghidupan yang lebih layak.

\section{Moral Ekonomi Pedagang}

Moral ekonomi pedagang muncul ketika para pedagang mengalami dilema yaitu memilih memenuhi kewajiban moral terhadap kerabat-kerabatnya ataupun tetangga-tetangganya untuk menikmati bersama pendapatan yang diperolehnya sendiri, disisi lain pedagang juga harus memenuhi kebutuhan akan kepentingan ekonomi mereka dengan mengakumulasikan modal dalam bentuk barang atau uang.

Moral, norma, dan nilai-nilai dapat berjalan apabila didalamnya terdapat atribut yaitu sifat atau tindakan untuk melakukan hal tersebut sehingga menghasilkan perilaku-perilaku yang benar dalam kehidupan (Soekanto, 1990).

Dilema yang dialami pedagang adalah dimana saat pedagang biasanya dikerumuni kerabatnya sebagai pembeli. Pedagang yang terlalu banyak didatangi oleh kerabatnya yang akan membeli barang dagangan mereka memiliki kemungkinan besar untuk bangkrut, kebangkrutan ini terjadi karena banyaknya potongan yang diberikan kepada kerabatnya bahkan kepada kerabat yang telah banyak berhutung pada mereka. Sedangkan kepada para tetangganya, pedagang tidak memberikan potongan hanya saja apabila tetangga tersebut telah menjadi pelanggan mereka, mereka memberikan kemudahan dalam menjual barang dagangannya kepada tetangga tersebut, misalnya seperti pelanggan berbelanja di kios mereka tetapi jumlah barang yang diinginkan tidak mencukupi nilai uang yang mereka bawa, di sini pedagang mengambil kebijakan untuk menawarkan bayar besok saja.
Moral ekonomi adalah suatu analisa tentang apa yang menyebabkan seseorang berperilaku, bertindak dan beraktivitas dalam kegiatan perekonomian. Hal ini dinyatakan sebagai gejala sosial yang berkemungkinan besar sangat berpengaruh terhadap tatanan kehidupan sosial. Sebagaimana yang dianut dan diterapkan oleh pedagang pasar Blauran Kota Palangka Raya.

Pedagang Pasar Blauran memiliki perangkat nilai budaya yang dijadikan pedoman dalam melakukan kegiatan berdagang di pasar Blauran Kota Palangka Raya. Pedoman nilai tersebut merupakan dasar dari moral ekonomi pedagang. moral dalam aspek kehidupan ekonomi adalah suatu tindakan ekonomi yang dilakukan oleh pelaku-pelaku ekonomi sesuai dengan etika atau tata tertib tingkah laku dalam pola bertindak dan berpikir yang dianggap baik dan benar di dalam aktivitas ekonomi. Nilai-nilai moral diletakkan di atas pertimbangan ekonomi di dalam setiap pengambilan keputusan untuk menjalankan usaha (Florence, 2008).

Moral ekonomi menjadi landasan bagi pedagang pasar Blauran Kota Palangka Raya untuk berdagang yang mencakup hal berhutang (debt), tolong menolong (mutual help), pengambilan keputusan (decision making) dan pengelolaan keuangan keluarga, menabung (saving), tawar menawar (bargaining) dan kepercayaan (trust).

Berdasarkan hasil penelitian terlihat bahwa moral ekonomi pedagang pasar Blauran Kota Palangka Raya terlihat adalah prinsip kepercayaan (trust) hal ini terlihat pedagang memberikan kepercayaan kepada pembeli untuk bayar belakangan (hutang) atas dasar rasa kepercayaan diantara mereka.

\section{Jurnal Sociopolitico}


Moral ekonomi seseorang didasari atas pengetahuan dan pengalaman yang dialami sehingga terbentuk nilai-nilai yang dianut seseorang dalam kegiatan ekonomi. pedagang seringkali mengalami dilema, hal inilah yang menyebabkan adanya pertentangan dalam diri para pedagang. Apabila pedagang menggunakan harga yang tinggi, maka dagangannya tidak akan laku, tetapi apabila pedagang menjual dagangannya dengan harga murah sedangkan modal sangat mahal maka kerugian akan dialami atau jika pedagang bermurah hati dengan menetapkan harga yang rendah atau memperpanjang jangka waktu pembayaran maka pedagang itu akan menghadapi kerugian juga.

\section{Jaringan Sosial}

Adanya jaringan-jaringan sosial yang erat dalam aktivitas perdagangan di pasar Blauran Kota Palangka Raya mempermudah para pedagang dalam mendapatkan barang dagangan serta mempertahankan pelanggannya. Jaringan sosial merupakan modal utama pada sektor perekonomian (Granovetter dalam Damsar, 2002)

Jaringan sosial ada dan berkembang membentuk satu kesatuan yang sulit untuk diputuskan, semua ini terjadi karena adanya rasa saling percaya yang timbul antara pedagang dan pemasok, dan pedagang terhadap pembeli yang selanjutnya menjadi pembeli tetap di kios tempat mereka berdagang atau dengan kata lain yaitu sebagai pelanggan.

Jaringan kekeluargaan merupakan dasar pembentuk hubungan modal sosial yang menciptakan kepercayaan dalam masyarakat, modal sosial mempengaruhi pertukaran ekonomi dalam dua bentuk yaitu kepercayaan dan emosi dalam suatu kelompok atau jaringan, dan keuntungan yang diperoleh secara langsung dengan mengenal pihak lain melalui jaringan. Dimana modal sosial dapat mengurangi biaya dalam memperoleh barang, difusi inovasi dan mereduksi resiko.

Dalam satu jaringan tata niaga biasa dijumpai banyaknya pedagang yang terlibat mulai dari pedagang pengumpul tingkat desa, pedagang pengumpul tingkat kecamatan, kemudian ke pedagang pengumpul yang lebih tinggi lagi sampai akhirnya ke pedagang antar daerah, antar pulau atau eksportir. Pada daerah pemasaran, barang akan berpindahpindah tangan lagi dari pedagang antar wilayah atau pulau kemudian ke pedagang grosir dan selanjutnya ke pedagang eceran.

\section{Strategi Pedagang}

Pedagang pasar Blauran memiliki strategi tersendiri dalam menghadapi persaingan dengan pasar modern, adapun strategi yang mereka jalankan adalah semata-mata untuk memajukan usaha mereka untuk meningkatkan penghasilan perekonomian dalam keluarga mereka masing-masing, ada berbagai macam reaksi yang ditunjukan oleh masingmasing pedagang di pasar tradisional ini, ada pedagang yang menunjukkan kesabaran dalam menghadapi pembeli, ada yang menujukan keuletan atau ketekunan dalam melayani pelanggan dengan mempergunakan mimik wajah yang ramah dan perkataan yang sopan untuk mendapatkan pelanggan yang semakin banyak. Sebagaimana pendapat Arifin (2008) bahwa strategi merupakan segala cara dan daya untuk menghadapi sasaran tertentu dalam kondisi tertentu agar memperoleh hasil yang diharapkan secara maksimal.

\section{Jurnal Sociopolitico}


Dari data yang ditemukan di lapangan terdapat beberapa strategi yang dijalankan oleh para pedagang pasar tradisional Blauran dalam melayani para pembeli sehingga mendapatkan banyak pelanggan yang berakibat kepada peningkatan perekonomian dari para pedagang. Adapun strategi-strategi itu ada yang aktif dan ada yang pasif.

Strategi aktif di sini adalah strategi yang mengoptimalkan segala potensi yang terdapat pada pedagang ataupun keluarga mereka untuk meningkatkan penghasilan perekonomian mereka. Mengerahkan segala kemampuan yang mereka miliki untuk dapat bertahan ditengah perekonomian yang semakin sulit karena kemunculan pasar modern yang semakin meluas, memaksa pedagang untuk menjalankan kegiatannya sebagai pedagang yang memiliki kemampuan untuk memanejemen usahanya dengan bantuan anggota keluarga yang mereka libatkan dalam menjalankan usaha berdagangnya. Dengan demikian ada kontinuitas dalam menjajakan barang dagangannya.

Dalam aktivitas ini, keluarga berperan penting dalam memajukan usaha keluarga mereka, berusaha melayani pembeli dan pelanggan dengan sebaik-baiknya merupakan strategi mereka dalam menarik pelanggan untuk membeli barang dagangan mereka. Selain itu, bersikap sopan dengan menggunakan bahasa yang sopan untuk melayani para pembeli juga merupakan strategi yang mereka gunakan untuk menarik pelanggan.

Strategi yang mereka jalankan merupakan strategi yang telah diturunkan turun temurun sejak mereka membantu ibunya terdahulu dalam berdagang, sehingga dengan lamanya pedagang berkecimpung dalam dunia perdagangan ini memudahkan mereka meneruskan usaha sebagai pedagang yang diturunkan kepada mereka.

Sekarang kegiatan itu telah berlangsung dengan memanfaatkan bantuan-bantuan dari anggota keluarga mereka ataupun anak-anak mereka untuk kemudian usaha yang mereka jalani sekarang akan diturunkan untuk anak mereka. Sedangkan strategi pasif di sini adalah penekanan pengeluaran ekonomi terhadap kebutuhan para pedagang, bagaimana pedagang dapat melakukan penekanan pengeluaran ekonomi mereka untuk menghindari resiko yang akan timbul apabila pengeluaran itu tidak diminimaliskan, contohnya adalah penekanan biaya transportasi dalam mendapatkan barang dagangan, mendekorasi bangunan kios agar terlihat menarik serta kebutuhan para pedagang setiap harinya.

Penekanan pengeluaran ini juga membantu mereka untuk hidup hemat, tidak menghambur-hamburkan uang untuk sesuatu yang tidak penting, disini mereka belajar untuk lebih menghargai uang dan berusaha hidup hemat, dengan demikian strategi pasif ini memberikan pengaruh positif bagi mereka untuk mendapatkan kehidupan yang lebih baik dengan tidak berfoya-foya, tetapi berhemat dan menyisihkan penghasilan untuk ditabung.

\section{Persepsi Pembeli}

Pembeli merupakan aktor penting dalam aktivitas perdagangan, karena proses jual beli baru akan terjadi apabila ada pembeli dan penjual dan melakukan tukar menukar barang dengan menggunakan mata uang yang berlaku.

Dalam penelitian ini pembeli merupakan salah satu informan yang

\section{Jurnal Sociopolitico}


dilibatkan untuk memperoleh informasi yang akurat mengenai aktivitas yang terjadi di pasar tradisional. Adapun persepsi dari pembeli mengenai faktorfaktor yang menyebabkan pembeli datang ke pasar tradisional daripada ke pasar modern adalah lokasi yang strategis (mudah dijangkau), kebersihan dan kenyamanan pasar, kelengkapan barang dagangan, kualitas dan harga barang dagangan, pelayanan dan yang terakhir sarana dan prasarana yang mendukung. Hal ini sesuai dengan pendapat Kotler \& Keller (Fadila dan Sari, 2013:45) persepsi tidak hanya tergantung pada rangsangan dalam bentuk fisik, tetapi juga tergantung pada rangsangan yang ada disekitarnya dan kondisi yang ada pada seseorang dan persepsi lebih penting dibandingkan realitas dalam pemasaran.

Adanya persepsi bahwa harga yang rendah menimbulkan persepsi produk tidak berkualitas. Harga terlalu rendah menimbulkan persepsi pembeli tidak percaya kepada penjual. Sebaliknya, harga yang tinggi menimbulkan persepsi penjual tidak percaya kepada pembeli, merupakan persepsi yang kurang tepat, misalnya harga sayuran lebih murah di pasar Blauran daripada harga di hypermart. Demikian pula dari segi kualitas, justru sayuran seperti wortel, kol, kentang, kacang yang dijual di Pasar Blauran lebih segar karena baru datang dibandingkan sayuran yang dijual di Hypermart karena dimasukkan di tempat pendingin sehingga bisa dirasakan dengan cara merabanya yang agak sedikit lembek.

Faktor persepsi pembeli yang kedua adalah berkaitan dengan pelayanan dari pedagang. Kalau di pasar Blauran Kota Palangka Raya, pembeli dapat berinteraksi langsung dengan pedagang, dapat menanyakan kondisi barang, kapan barang ada, baru apa sudah lama dari satu pedagang ke pedagang lain, sehingga pembeli memiliki banyak pilihan sebelum memutuskan untuk membeli. Sedangkan kalau belanja di hypermart, pembeli tidak bisa berinteraksi dengan pedagang, karena pembeli tinggal melihat produk dagangan dan harga yang sudah dipajang, apabila suka maka tinggal bungkus barang tersebut kemudian diserahkan kepada pelayan untuk ditimbang dan diberi harganya.

Di sini pembeli tidak bisa berinteraksi dengan pelayanan berkaitan dengan produk barang yang dijual karena pelayan hanya sebatas melayani pembelian saja bukan untuk menceritakan tentang produk yang dijualnya. Hal ini sesuai dengan pendapat Simamora dalam Ramadhan (2013) bahwa salah satu faktor yang mempengaruhi persepsi adalah pelayanan yaitu kemampuan memberikan layanan kepada pelanggan.

Persepsi pembeli yang selanjutnya adalah berkaitan dengan kebersihan dan kenyamanan. Kondisi ini jelas mencolok berbeda karena memang terlihat bahwa dari faktor kebersihan dan kenyamanan, kondisi di pasar Blauran Kota Palangka Raya masih kurang bersih dan nyaman, karena masih banyak genangan air, becek dan yang penting baunya kurang sedap. Hal ini berlawanan dengan kondisi di pasar modern yang suasananya bersih dan nyaman, kemudian ada pendingan udara sehingga begitu masuk hypermart terasa sejuk sehingga pembeli merasa nyaman berlama-lama di hypermart.

Berkaitan dengan kelengkapan barang dagangan, kalau dilihat berdasarkan jenis sayuran, pasar Blauran Kota Palangka Raya lebih banyak jenisnya daripada yang dijual di hypermat. Demikian pula dari segi jumlah barang

\section{Jurnal Sociopolitico}


dagangan jenis sayuran, pasar Blauran Kota Palangka Raya lebih banyak jumlahnya dibanding dengan jumlah yang dijual di hypermart. Namun untuk barangbarang tertentu juga ada yang tidak dijual di pasar Blauran, sedangkan di hypermart ada menjual barang tersebut. Jadi berdasarkan kelengkapan jenis barang dagangannya dapata dikatakan bersifat relatif antara pasar tradisional Blauran dengan pasar modern, tergantung jenis barang apa yang dicari oleh pembeli.

Faktor persepsi yang terakhir adalah faktor kelengkapan sarana dan prasarana pendukung. Sebenarnya hal ini juga bersifat relatif, namun kenyataannya bahwa faktor sarana dan prasarana pendukung seperti tempat parkir, tempat ibadah, dan tempat bermain anak, di hypermart jelas lebih lengkap tersedia dengan kondisi yang lebih bersih dan nyaman, dibandingkan dengan sarana dan prasarana di pasar Blauran Kota Palangka Raya yang masih kurang teratur. Bahkan untuk area parkir harus mengambil badan jalan sehingga tidak jarang menimbulkan kemacetan dan kesemrawutan lalu lintas di pasar Blauran Kota Palangka Raya.

\section{Kesimpulan}

Dinamika sosial pedagang di pasar Blauran Kota Palangka Raya maka dapat disimpulkan sebagai berikut:

1. Etos kerja pedagang diwujudkan dalam bentuk kerapian, sopan santuan. keikhlasan dan kesabaran, dipengaruhi oleh norma-norma dan budaya yang diyakini oleh para pedagang.

2. Moral ekonomi pedagang diwujudkan dalam bentuk kepercayaan (trust) yang diberikan pedagang kepada pembeli dengan cara memberikan hutang dagang yang dibayarkan beberapa hari kemudian, dengan membawa barang dagangannya terlebih dahulu.

3. Adanya jaringan sosial yang terjalin diantara pemasok, pedagang, pembeli dan pelanggan menyebabkan tidak terputusnya aktivitas di pasar Blauran, sehingga stok barang dagangan tetap terjaga sehingga dapat mempertahankan pelanggannya.

4. Strategi pedagang untuk berjualan adalah kesabaran dalam menghadapi pembeli, ada yang menujukan keuletan atau ketekunan dalam melayani pelanggan dengan mempergunakan mimik wajah yang ramah dan perkataan yang sopan untuk mendapatkan pelanggan yang semakin banyak.

5. Persepsi pembeli dipengaruhi oleh lokasi yang strategis (mudah dijangkau), kebersihan dan kenyamanan pasar, kelengkapan barang dagangan, kualitas dan harga barang dagangan, pelayanan dan yang terakhir sarana dan prasarana yang mendukung.

\section{Referensi}

Arifin, M. (2008). Psikologi Suatu Pengantar. Jakarta: PT Bumi Aksara.

Damsar. (2002). Sosiologi Ekonomi Edisi Revisi. Jakarta: PT Raja Grafindo Persada.

Fadila, Dewi \& Sari Lestari Zainal Ridho. (2013). Perilaku Konsumen. Palembang: Citrabooks Indonesia.

Florence. (2008). Moral Ekonomi Pedagang Komunitas Etnik India. http://repository. usu.ac id /bitstream /123456789/ 30526/4/Chapter\% 20I. pdf. Skripsi.

\section{Jurnal Sociopolitico}


Medan: Universitas Sumatera Utara.

Diakses pada 10 Januari 2019

Fuad, M, dkk. (2000). Pengantar Bisnis. Jakarta: PT Gramedia.

Masitoh, Eis. (2013) Upaya Menjaga Eksistensi Pasar Tradisional (Studi Revitalisasi Pasar Piyungan Bantul. Jurnal PMI Vol. X. No. 2.

Mubyarto. (1991). Pengantar Ekonomi Pertanian. Jakarta: LP3ES.

Ramadhan, Rahmat. (2013). Persepsi Mahasiswa Terhadap Penggunaan Poduk Smartphone Blackberry (Studi Kasus Pada Mahasiswa Politeknik Negeri Jurusan Teknik Kimia). Jurusan Administrasi Bisnis Polsri. Laporan Akhir (Tidak di Publikasikan): Polsri.

Santoso, Slamet. (2009). Dinamika Kelompok. Jakarta: Bumi Aksara.

Sarajar. (1995).Persepsi Tentang Etos Kerja, Kaitannya Dengan Nilai Budaya Masyarakat Di Daerah Sulawesi Utara. Departemen Pendidikan dan Kebudayaan 1995/1996.

Sinamo, Jansen. (2011). Delapan Etos Kerja Profesional. Jakarta: Institut Mahardika.

Soekanto, Soerjono. (1990). Sosiologi Suatu Pengantar. Jakarta: Rajawali Press.

(2006). Sosiologi Suatu Pengantar. Jakarta: Raja Grafindo Persada.

Tasmara, Toto. (1995). Membudayakan Etos Kerja Islami. Jakarta: Gema Insani 